\title{
Dietary Supplementation of Alternative Methionine and Choline Sources in the Organic Broiler Production in Brazil
}

-Author(s)

\section{Demattê Filho LC \\ Pereira DC de O" \\ Possamai EIII}

DVM -General Coordinator of the Mokiti Okada Research Center - CPMO. PhD in Applied Ecology -CENA/ESALQ-USP

" Animal Scientist - Researcher at Mokiti Okada Research Center - CPMO, MSc student in the MBA program in Engineering Farming Systems, ESALQ-USP,

III Production Manager at Korin Agropecuária Ltd.

\section{Mail Address}

Corresponding author e-mail address Dayana Cristina de Oliveira Pereira

Estrada Municipal de Camaquã, Km 82, Ipeúna - SP - Brasil.

CEP: 13537000, Caixa Postal: 033

Email: dayana.pereira@cpmo.org.br

\section{- Keywords}

Choline, DL-methionine 99\%, organic agriculture, organic broiler.

\section{ABSTRACT}

The objective of this study was to evaluate the use of natural and alternative sources of methionine and choline which can be allowed to use in organic livestock systems to feed broilers produced in Brazil. Seven hundred and twenty one-d-old male Cobb broilers were randomly allocated to four treatments with six replicates of 24 birds each. The treatments consisted in substituting the commonly used DL-methionine $99 \%$ by a vegetable source of methionine and cholinechloride $60 \%$ by alternative source of choline in the form of phosphatidylcholine. The following treatments were evaluated: I) feed with DL-methionine $99 \%$ and choline chloride $60 \%$, II) feed with an vegetable methionine source and choline chloride $60 \%$, III) feed with DL-methionine $99 \%$ and choline as phosphatidylcholine, and IV) feed with vegetable methionine source and choline as phosphatidylcholine. Daily weight gain, body weight, feed intake, feed conversion ratio, and mortality were evaluated for the periods of 1 to 21 and 1 to 42 days of age. During both periods, broilers fed the vegetable methionine source presented lower daily gain and lower body weight. When only choline chloride was substituted by the alternative choline source, broiler performance was not different compared with that of the control group. The group fed the diet with substitution of both DL-methionine $99 \%$ and choline chloride $60 \%$ by natural sources presented lower daily weight gain, final body weight, and feed intake. Further research on alternative nutrient sources are required for the development of the organic production chain.

\section{INTRODUCTION}

According to Ubabef (2014), the Brazilian production of chicken meat was 12.30 million tones. In this context, Brazil is the third largest producer and the first exporter of this product in the world.

In part, this gigantism of poultry industry is driven by the availability of feedstuffs. This accessibility is a direct reflection of a very well structured supply chain, which allows producers to take advantage of the natural potential of the country to produce grains, such as corn and soybeans.

According to Bonaudo et al. (2010) and Demattê Filho \& Marques (2011), assessing the diversity of the Brazilian meat supply chain, determined that the poultry production follows an industrial model, constantly seeking to reduce costs and presenting a strong coordination between agents, which generate a very cohesive agro-industrial structure, and consequently, outstanding competitiveness.

Nevertheless, despite the many companies producing regular chicken meat in Brazil, only one applies organic production methods, and in a very small scale (Korin2012). One of the strongest barrier for the expansion of this production model is the price of the final product-, 
which is usually two to three fold higher than regular ones. According to Buainain et al. (2007) the cost of this production model, depending on the product and the season, it can be200\% more expensive than that achieved by conventional industrial systems.

Differently fromthe conventional system, the organic system does not have a well-structured supply chain, resulting in several limitations, such as low availability of grains, especially of corn and soybeans, both in terms of quantity and quality, throughout the year (Korin, 2012).

Additionally, the standards imposed by the rules of organic production, such as forbidding the use of synthetic amino acids, negatively affecting production efficiency by preventing the expression of the maximum production potential of broilers. Organic broilers are produced, processed, distributed, and marketed under specific norms, which are verified and certified by third-party bodies or through voluntary participatory certification process (Brasil, 2011). The rules for organic broiler production in Brazil are currently established by Act n. 10.831 (Brasil, 2003) and its normative instructions ( $\mathrm{NI}$ ), especially $\mathrm{NI}$ n. 46 and $\mathrm{NI}$ n.17, which specify the rules for the production of livestock and crops under organic systems (Brasil, 2011). Considering the lack of information on the nutritional and financial viability of organic production, this paper focuses on the attempt to replace synthetic sources of amino acids and vitamins commonly used for poultry by natural sources. This study aimed at identifying natural amino acid sources that may be allowed by organic livestock production regulations and certification bodies, and that may provide positive results in organic chicken production.

\section{MATERIALS AND METHODS}

The study was conducted at the experimental facilities of Korin Agropecuária Ltd., located in the municipality of Ipeúna, state of São Paulo, Brazil, between February and April of 2012. Seven hundred and twenty one-d-old male Cobb broilers were vaccinated at the hatchery against Marek's disease, avian fowlpox, infectious bursal disease, and coccidiosis. Average initial body weight was $46.04 \mathrm{~g} \pm 0.89 \mathrm{~g}$.

Birds were housed in a conventional open-sided masonry chicken house $(8.0 \mathrm{~m} \times 30.0 \mathrm{~m})$, with concrete floors, 3.0m ceiling height and rood covered with clay tiles. Gas hoods were used for brooding in the first experimental week. The experimental housed was equipped with four fans for air circulation, and the thermal comfort range and lighting program followed the recommendations of the genetic strain manual. Average minimum and maximum temperatures of $22.3^{\circ} \mathrm{C}$ and $31.4^{\circ} \mathrm{C}$ (average of $26.8^{\circ} \mathrm{C}$ ) were recorded. The experiment lasted 42 days.

The chicks were allocated to 24 pens $(1.0 \mathrm{~m} \times$ $2.5 \mathrm{~m}$ ) of 30 birds each, thereby complying with the requirement of a maximum density of 12 birds/ $\mathrm{m}^{2}$. The experimental diets were based on corn and soybean meal, formulated according to the nutritional recommendations of Rostagno et al.,(2011), with no inclusion of coccidio stats, antibiotics, or animal byproducts. A 5-phasefeeding strategy was applied, and included pre-starter (1-7 days of age), starter (821 days), grower I (22-30 days), grower II (31-37 days), and finisher (38-42 days) periods. Feed and water were available ad libitum.

The treatments consisted of four diets: a control diet, containing the conventional synthetic amino acid DL-methionine 99\% and choline chloride 60\%; a diet where synthetic methionine was replaced by a vegetable methionine source, primarily extracted from soybeans, which, according to the manufacturer, has 99\% methionine content; a diet where choline chloride was replaced by a natural choline source in the form of phosphatidylcholine, a product of the company Techno feed marketed under the trade name Biocholine Powder $\AA$; and a diet where both synthetic DL-methionine and choline chloride were replaced by their respective natural sources (Table 1). The ingredients and the nutritional composition of the experimental diets are shown in Tables 4, 5 and 6.

Both alternative products were included at the levels recommended by the manufacturers. Natural choline was added to the diets at the ratio $1 / 3$ of

Table 1 - Description of the abbreviations of treatments.

\begin{tabular}{|c|c|c|c|}
\hline Treatments & Abbreviations & Source of methionine & Source of choline \\
\hline Control & Control & 99\% DL-methionine & choline chloride at $60 \%$ \\
\hline Alternative methionine source & VM & vegetable methionine & choline chloride at $60 \%$ \\
\hline Alternative choline source & $A C$ & 99\% DL-methionine & choline as phosphatidylcholine \\
\hline Alternative methionine and choline sources & VMAC & vegetable methionine & choline as phosphatidylcholine \\
\hline
\end{tabular}

Treatments evaluated in the article: Dietary supplementation of alternative methionine and choline in the production of organic broilers in Brazil. 
choline chloride $60 \%$, and vegetable methionine was included at the same ratio as $99 \%$ DL-methionine.

Live performance parameters were evaluated for the periods 1 to 21 and 1 to 42 days of age. Body weight gain (BW) was calculated as the difference between final weight and initial weight for each investigated period. Birds were weighed per pen (experimental unit). Feed intake was calculated as the difference between the total feed supplied and feed residues remaining at the end of each feeding phase. Feed conversion rate (FCR) was calculated as the ratio between total feed intake and weight gain, corrected for mortality, as proposed by Sakomura \& Rostagno (2007). Mortality (MO) was daily recorded. The production efficiency index was calculated using the following equation: PEI $\left.=(B W *(100-M O)) / A g e^{*} F C R\right)^{*} 100$. The evaluation of the production cost took into consideration the price of feedstuffs and a carcass yield of $75 \%$. The price of the final product was obtained in large supermarket chains.

Broilers were distributed in a completely randomized design, consisting of four treatments with six replicates of 30 broilers each, totaling 180 birds per treatment. Data were statistically analyzed using Sisvar software (Ferreira, 2008), and the differences between treatments were compared by the Student-Newman Keuls test (SNK) at5\% significance levels. Data on mortality was subjected to $\log (x+c)$ transformation prior the statistical tests.

\section{RESULTS AND DISCUSSION}

Broilers fed the vegetal source of DL-methionine (VM) presented lower daily weight gain feed intake $(p<0.05)$ during both evaluated periods compared with the control group (Table 2). When only choline chloride was replaced by alternative source of choline chloride $60 \%(A C)$, performance variables no performance differences were detected relative to the control group during the same periods (Table 2). The substitution of both synthetic DL-methionine $99 \%$ and choline chloride60\% (VMAC) resulted in lower daily weight gain, final body weight, and feed intake compared with the control group (Table 2). In addition, broilers in the groups fed VM presented worse feed conversion ratio $(p<0.05)$ than the $A C$ and the control groups considering the entire experimental period (142 days). No differences in mortality were observed among groups in any of the periods.

Based on the information that both products contained the same percentage of methionine, the lower performance observed when synthetic DLmethionine $99 \%$ was replaced by the methionine of vegetable source (VM) was possibly due to differences in the absorption of both sources of amino acids. Partridge et al. (1985) reported that amino acid absorption depends on their source, and that the absorption of synthetic amino acids is more efficient than amino acids available in vegetal sources. The same authors highlighted that free (synthetic) amino

Table 2 - Performance parameters (mean \pm standard error): average daily gain (ADG) final body weight (FBW), feed intake $(\mathrm{FI})$, feed conversion ratio (FCR), and mortality (MO) of broilers fed the experimental diets during the periods of 1 to 21 and 1 to 42 days.

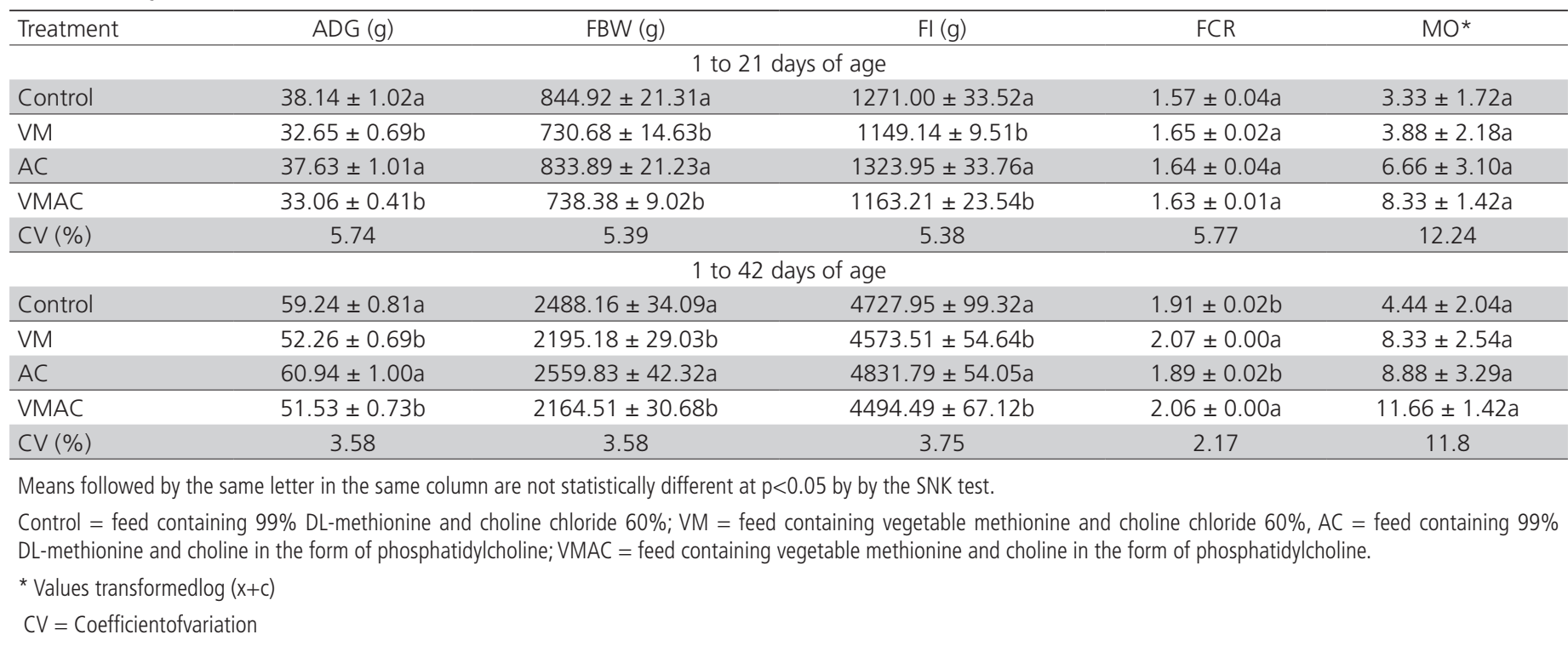


Table3 - Effect of treatments on production efficiency index (PEI), feed costs, and the cost of production of $100 \mathrm{~kg}$ of meat.

\begin{tabular}{lccccc}
\hline Treatments & \multirow{2}{*}{ EPI } & \multirow{2}{*}{ Cost } & $* *$ Feed intake & $\begin{array}{c}* * * \text { Cost to produce } 100 \mathrm{~kg} \\
\text { of meat }\end{array}$ & $\begin{array}{c}* * * * \text { Average price of chicken } \\
\text { meat } / \mathrm{Kg}\end{array}$ \\
\hline Control & $295.60 \mathrm{a}$ & $\mathrm{R} \$ 64.60$ & 254.66 & $\mathrm{R} \$ 164.51$ & $\mathrm{R} \$ 9.00$ \\
VM & $230.75 \mathrm{~b}$ & $\mathrm{R} \$ 64.80$ & 276.71 & $\mathrm{R} \$ 179.31$ & $\mathrm{R} \$ 13.77$ \\
\hline $\mathrm{AC}$ & $293.79 \mathrm{a}$ & $\mathrm{R} \$ 64.60$ & 252.00 & $\mathrm{R} \$ 162.79$ & $\mathrm{R} \$ 9.00$ \\
VMAC & $220.93 \mathrm{~b}$ & $\mathrm{R} \$ 64.80$ & 274.60 & $\mathrm{R} \$ 177.94$ & $\mathrm{R} \$ 13.77$ \\
\hline
\end{tabular}

Means followed by the same letter in the same column are not statistically different at $p<0.05$ by the SNK test.

Control = feed containing 99\% DL-methionine and choline chloride 60\%; VM = feed containing vegetable methionine and choline chloride 60\%, AC = feed containing 99\%

DL-methionine and choline in the form of phosphatidylcholine; VMAC = feed containing vegetable methionine and choline in the form of phosphatidylcholine.

${ }^{*}$ Cost of $100 \mathrm{~kg}$ of feed, considering the cost of the raw materials obtained in the state of São Paulo in 2012.

** Feed intake required to produce $100 \mathrm{~kg}$ of meat

*** Cost to produce $100 \mathrm{~kg}$ of meat, considering only feed and a carcass yield of $75 \%$.

**** Sales price in the market of organic and antibiotic-free chickens.

acids are more available to animals, resulting in a faster absorption.

The absorption of the plant methionine source used in the present study was possibly lower than that of synthetic methionine, and considering that methionine is the first limiting amino acid in broiler nutrition, this resulted in worse performance. In contrast, when only choline chloride $60 \%$ was substituted by AC, broiler performance is not statistically influenced. This is probably due to the fact that broilers are able to synthesize choline when its precursors are available in adequate amounts (Lisboa et al., 2014). In addition,

Table 4 - Ingredients and calculated nutritional composition of the experimental diets fed during the initial and grower phases

\begin{tabular}{|c|c|c|c|c|c|c|c|c|}
\hline \multirow{2}{*}{ Ingredients (\%) } & \multicolumn{4}{|c|}{ Initial (1-7 days of age) } & \multicolumn{4}{|c|}{ Growth (8-21 days of age) } \\
\hline & Control & VM & $A C$ & VMAC & Control & VM & $A C$ & VMAC \\
\hline Corn & 58,34 & 58,34 & 58,38 & 58,38 & 56,83 & 56,83 & 56,86 & 56,86 \\
\hline Full fat soybean & --- & --- & --- & --- & 12,60 & 12,60 & 12,60 & 12,60 \\
\hline Soybean meal & 38,40 & 38,40 & 38,40 & 38,40 & 27,50 & 27,50 & 27,50 & 27,50 \\
\hline Dicalcium phosphate & 1,10 & 1,10 & 1,10 & 1,10 & 1,00 & 1,00 & 1,00 & 1,00 \\
\hline Limestone & 1,00 & 1,00 & 1,00 & 1,00 & 0,95 & 0,95 & 0,95 & 0,95 \\
\hline $\mathrm{NaCl}$ & 0,38 & 0,38 & 0,38 & 0,38 & 0,40 & 0,40 & 0,40 & 0,40 \\
\hline Mineral/vitamin premix ${ }^{1}$ & 0,28 & 0,28 & 0,28 & 0,28 & 0,28 & 0,28 & 0,28 & 0,28 \\
\hline L-lysine $\mathrm{HCl}$ & 0,13 & 0,13 & 0,13 & 0,13 & 0,10 & 0,10 & 0,10 & 0,10 \\
\hline DL-methionine 99 & 0,27 & --- & 0,27 & --- & 0,26 & --- & 0,26 & --- \\
\hline Alternative methionine & --- & 0,27 & --- & 0,27 & --- & 0,26 & --- & 0,26 \\
\hline L-threonine & 0,03 & 0,03 & 0,03 & 0,03 & 0,02 & 0,02 & 0,02 & 0,02 \\
\hline Choline chloride $60 \%$ & 0,06 & 0,06 & --- & --- & 0,055 & 0,055 & --- & --- \\
\hline Phosphatidylcholine & --- & --- & 0,02 & 0,02 & --- & $\ldots$ & 0,018 & 0,018 \\
\hline Phytase & 0,01 & 0,01 & 0,01 & 0,01 & 0,01 & 0,01 & 0,01 & 0,01 \\
\hline Total & 100 & 100 & 100 & 100 & 100 & 100 & 100 & 100 \\
\hline Metabolizable energy $(\mathrm{Kcal} / \mathrm{Kg})$ & 2.946 & 2.946 & 2.946 & 2.946 & 3.080 & 3.080 & 3.080 & 3.080 \\
\hline Crude protein (\%) & 23,00 & 23,00 & 23,00 & 23,00 & 22,49 & 22,49 & 22,49 & 22,49 \\
\hline Calcium (\%) & 0,88 & 0,88 & 0,88 & 0,88 & 0,83 & 0,83 & 0,83 & 0,83 \\
\hline Sodium (\%) & 0,18 & 0,18 & 0,18 & 0,18 & 0,18 & 0,18 & 0,18 & 0,18 \\
\hline Fosforo (\%) & 0,58 & 0,58 & 0,58 & 0,58 & 0,56 & 0,56 & 0,56 & 0,56 \\
\hline Total de lysine (\%) & 1,33 & 1,33 & 1,33 & 1,33 & 1,28 & 1,28 & 1,28 & 1,28 \\
\hline Total methionine + cystine (\%) & 1,00 & $1,00 *$ & 1,00 & $1,00 *$ & 0,97 & $0,97 *$ & 0,97 & 0,97 * \\
\hline Total methionine (\%) & 0,63 & $0,63^{*}$ & 0,63 & $0,63^{*}$ & 0,61 & 0,61 * & 0,61 & 0,61 * \\
\hline Total threonine (\%) & 0,90 & 0,90 & 0,90 & 0,90 & 0,87 & 0,87 & 0,87 & 0,87 \\
\hline Choline (PPM) & 1.409 & 1.409 & $1.409^{*}$ & $1.409^{*}$ & 1.360 & 1.360 & $1.360^{*}$ & $1.360 *$ \\
\hline
\end{tabular}

Control = feed containing 99\% DL-methionine and choline chloride 60\%; VM = feed containing vegetable methionine and choline chloride $60 \%$, AC = feed containing $99 \%$

DL-methionine and choline in the form of phosphatidylcholine; VMAC = feed containing vegetable methionine and choline in the form of phosphatidylcholine

1 Supplemented per kilogram of premix: Fe 7200mg; Cu 1440mg; Mn 14,40g; Zn 10,80g; I 180mg; Se 36mg; Vit A 1200000IU; Vit D3 300000IU; Vit E 3000IU; Vit K3 436,80mg; Vit B1 288mg; Vit B2 720mg; Niacin 4000mg; Pantothenic acid 1560mg; Vit B6 384mg; Folic acid 200mg; Vit B12 1880mg.

* Calculated in the agreement with the security level available for manufacturer. 
Table5 - Ingredients and calculated nutritional composition of the experimental diets fed during the fattening I and fattening II phases

\begin{tabular}{|c|c|c|c|c|c|c|c|c|}
\hline \multirow{2}{*}{ Ingredients (\%) } & \multicolumn{4}{|c|}{ Fattening I (22-30 days of age) } & \multicolumn{4}{|c|}{ Fattening II (31-37 days of age) } \\
\hline & Control & VM & $A C$ & VMAC & Control & VM & $A C$ & VMAC \\
\hline Corn & 58,37 & 58,37 & 58,40 & 58,40 & 64,87 & 64,87 & 64,90 & 64,90 \\
\hline Full fat soybean & 24,70 & 24,70 & 24,70 & 24,70 & 18,80 & 18,80 & 18,80 & 18,80 \\
\hline Soybean meal & 13,90 & 13,90 & 13,90 & 13,90 & 13,50 & 13,50 & 13,50 & 13,50 \\
\hline Dicalcium phosphate & 0,90 & 0,90 & 0,90 & 0,90 & 0,90 & 0,90 & 0,90 & 0,90 \\
\hline Limestone & 0,80 & 0,80 & 0,80 & 0,80 & 0,80 & 0,80 & 0,80 & 0,80 \\
\hline $\mathrm{NaCl}$ & 0,40 & 0,40 & 0,40 & 0,40 & 0,40 & 0,40 & 0,40 & 0,40 \\
\hline Mineral/vitamin premix ${ }^{2}$ & 0,26 & 0,26 & 0,26 & 0,26 & 0,26 & 0,26 & 0,26 & 0,26 \\
\hline L-lysine $\mathrm{HCl}$ & 0,24 & 0,24 & 0,24 & 0,24 & 0,17 & 0,17 & 0,17 & 0,17 \\
\hline DL-methionine 99 & 0,28 & --- & 0,28 & --- & 0,23 & --- & 0,23 & --- \\
\hline Alternative methionine & --- & 0,28 & --- & 0,28 & --- & 0,23 & --- & 0,23 \\
\hline L-threonine & 0,09 & 0,09 & 0,09 & 0,09 & 0,02 & 0,02 & 0,02 & 0,02 \\
\hline Choline chloride $60 \%$ & 0,050 & 0,050 & --- & --- & 0,045 & 0,045 & --- & --- \\
\hline Phosphatidylcholine & --- & --- & 0,016 & 0,016 & --- & --- & 0,015 & 0,015 \\
\hline Phytase & 0,01 & 0,01 & 0,01 & 0,01 & 0,01 & 0,01 & 0,01 & 0,01 \\
\hline Total & 100 & 100 & 100 & 100 & 100 & 100 & 100 & 100 \\
\hline Metabolizable energy (Kcal/Kg) & 3.250 & 3.250 & 3.250 & 3.250 & 3.250 & 3.250 & 3.250 & 3.250 \\
\hline Crude protein (\%) & 21,00 & 21,00 & 21,00 & 21,00 & 19,03 & 19,03 & 19,03 & 19,03 \\
\hline Calcium (\%) & 0,74 & 0,74 & 0,74 & 0,74 & 0,73 & 0,73 & 0,73 & 0,73 \\
\hline Sodium (\%) & 0,18 & 0,18 & 0,18 & 0,18 & 0,184 & 0,184 & 0,184 & 0,184 \\
\hline Fosforo (\%) & 0,54 & 0,54 & 0,54 & 0,54 & 0,51 & 0,51 & 0,51 & 0,51 \\
\hline Total de lysine (\%) & 1,28 & 1,28 & 1,28 & 1,28 & 1,10 & 1,10 & 1,10 & 1,10 \\
\hline Total methionine + cystine (\%) & 0,95 & $0,95^{*}$ & 0,95 & $0,95^{*}$ & 0,86 & $0,86^{*}$ & 0,86 & $0,86^{*}$ \\
\hline Total methionine (\%) & 0,61 & $0,61 *$ & 0,61 & $0,61 *$ & 0,54 & $0,54^{*}$ & 0,54 & $0,54^{*}$ \\
\hline Total threonine (\%) & 0,87 & 0,87 & 0,87 & 0,87 & 0,73 & 0,73 & 0,73 & 0,73 \\
\hline Choline (PPM) & 1.260 & 1.260 & $1.260 *$ & $1.260 *$ & 1.160 & 1.160 & $1.160^{*}$ & $1.160 *$ \\
\hline
\end{tabular}

Control = feed containing 99\% DL-methionine and choline chloride 60\%; VM = feed containing vegetable methionine and choline chloride $60 \%$, AC = feed containing $99 \%$ DL-methionine and choline in the form of phosphatidylcholine; VMAC = feed containing vegetable methionine and choline in the form of phosphatidylcholine

2Supplemented per kilogram of premix: Fe 6000mg; Cu 1200mg; Mn 12g; Zn 9000mg; I 150mg; Se 36mg; Vit A 1000000IU; Vit D3 250000IU; Vit E 2500IU; Vit K3 364mg; Vit B1 240mg; Vit B2 600mg; Niacin 3200mg; Pantothenic acid 1400mg; Vit B6 320mg; Folic acid 160mg; Vit B12 1560mcg.

${ }^{*}$ Calculated in the agreement with the security level available for manufacturer.

one of the main roles of choline is to donate methyl radicals, as well as methionine (Silva et al., 2010). These features may explain the inferior live performance when both synthetic methionine and choline were replaced in the diet (VMAC)compared with broilers consuming the diet where choline chloride $60 \%$ (AC) was replaced.

Although the use of the vegetal methionine source resulted in inferior performance compared with synthetic DL-methionine $99 \%$, it is a valuable ingredient to be used in organic production systems where synthetic amino acids are not allowed.

Based on production data and also on the observations of the company's technical team (Korin, 2012), the use of the vegetal source of methionine for broilers and egg layers managed in organic systems presented superior results when compared with birds not supplemented with the vegetal methionine source. New research on the bioavailability of nutrients from natural sources may promote further improvements of the production indices.

The emergence of new sources of choline, as well as the possibility to add vegetable sources of methionine to broiler diets, are a breakthrough in the search for strengthening the production chain of organic chickens. Their use improves production efficiency and reduces the need for incorporating new protein sources in feeding strategies. Such aspects will contribute to reduce production costs and to minimize the excretion of minerals by birds, particularly nitrogen and phosphorus.

Financially, the lower productive efficiency index is compensated by the market value of organic animal products, which is generally much higher than that obtained by conventional products (Table 3). According with Demattê Filho (2014), the production of organic broilers at commercial scale only succeeds due to price differences, since there is a reduction in yield. 
Table 6 - Ingredients and calculated nutritional composition of the experimental diet fed during the Final phases

\begin{tabular}{|c|c|c|c|c|}
\hline \multirow{2}{*}{ Ingredients (\%) } & \multicolumn{4}{|c|}{ Final (38-42 days of age) } \\
\hline & Control & VM & $A C$ & VMAC \\
\hline Corn & 66,65 & 66,65 & 66,68 & 66,68 \\
\hline Full fat soybean & 22,00 & 22,00 & 22,00 & 22,00 \\
\hline Soybean meal & 8,90 & 8,90 & 8,90 & 8,90 \\
\hline Dicalcium phosphate & 0,70 & 0,70 & 0,70 & 0,70 \\
\hline Limestone & 0,80 & 0,80 & 0,80 & 0,80 \\
\hline $\mathrm{NaCl}$ & 0,40 & 0,40 & 0,40 & 0,40 \\
\hline Mineral/vitamin premix ${ }^{3}$ & 0,26 & 0,26 & 0,26 & 0,26 \\
\hline L-lysine $\mathrm{HCl}$ & 0,06 & 0,06 & 0,06 & 0,06 \\
\hline DL-methionine 99 & 0,18 & --- & 0,18 & --- \\
\hline Alternative methionine & --- & 0,18 & --- & 0,18 \\
\hline Choline chloride $60 \%$ & 0,035 & 0,035 & --- & --- \\
\hline Phosphatidylcholine & --- & --- & 0,012 & 0,012 \\
\hline Phytase & 0,01 & 0,01 & 0,01 & 0,01 \\
\hline Total & 100 & 100 & 100 & 100 \\
\hline Metabolizable energy (Kcal/Kg) & 3.310 & 3.310 & 3.310 & 3.310 \\
\hline Crude protein (\%) & 18,05 & 18,05 & 18,05 & 18,05 \\
\hline Calcium (\%) & 0,68 & 0,68 & 0,68 & 0,68 \\
\hline Sodium (\%) & 0,18 & 0,18 & 0,18 & 0,18 \\
\hline Fosforo (\%) & 0,48 & 0,48 & 0,48 & 0,48 \\
\hline Total de lysine (\%) & 0,96 & 0,96 & 0,96 & 0,96 \\
\hline Total methionine + cystine (\%) & 0,79 & $0,79 *$ & 0,79 & $0,79 *$ \\
\hline Total methionine (\%) & 0,48 & $0,48^{*}$ & 0,48 & $0,48^{*}$ \\
\hline Total threonine (\%) & 0,68 & 0,68 & 0,68 & 0,68 \\
\hline Choline (PPM) & 1.073 & 1.073 & $1.073^{*}$ & $1.073^{*}$ \\
\hline
\end{tabular}

Control = feed containing 99\% DL-methionine and choline chloride 60\%; VM = feed containing vegetable methionine and choline chloride $60 \%$, AC = feed containing $99 \%$ DL-methionine and choline in the form of phosphatidylcholine; VMAC = feed containing vegetable methionine and choline in the form of phosphatidylcholine

3Supplemented per kilogram of premix: Fe 7500mg; Cu 1500mg; Mn 15g; Zn 11,25g; I 187,50mg; Se 45mg; Vit A 1250000IU; Vit D3 306250IU; Vit E 2500IU; Vit K3 455mg; Vit B1 300mg; Vit B2 750mg; Niacin 4000mg; Pantothenic acid 1750mg; Vit B6 400m; Folic acid 200mg; Vit B12 1950mcg.

${ }^{*}$ Calculated in the agreement with the security level available for manufacturer.

The emergence of alternative products, such as those evaluated in the present study, demonstrates the gradual development of the supply chain for the commercial production of chickens in organic systems. Such technological development are promising, and will make organic poultry production more attractive to the farmers and more accessible to the population.

\section{CONCLUSIONS}

The replacement of choline chloride $60 \%$ by choline in the form of phosphatidylcholine did not affect broiler performance. However, the substitution of DLmethionine $99 \%$ by a vegetable source of methionine resulted in worse performance.

The bioavailability of natural nutrients, especially of natural methionine sources, with respect to its ability to donate methyl radicals, should be further investigated in order to better evaluate its role in organic production.

\section{REFERÊNCIAS}

BRASIL. Presidência da República. Atos do Poder Legislativo. Dispõem sobre a agricultura orgânica e da outras providencias. Aprovado pela Lei n. 10.831 de 23 de dezembro de 2003. Diário Oficial da União, Brasília; 2003 [cited 2013 Jul 31]. Available from: http://www.in.gov. br/visualiza/index.jsp?data=24/12/2003\&jornal=1 \&pagina=1\&totalArq uivos $=332$.

BRASIL. Ministério da Agricultura, Pecuária e Abastecimento. Regulamento técnico para os sistemas orgânico de produção animal e vegetal. Aprovado pela Instrução Normativa n. 46, de 06 de outubro de 2011. Diário Oficial da União, Brasília; 07 out. 2011.

BRASIL. Ministério da Agricultura. Pecuária e Abastecimento - MAPA. Instrução Normativa n.17. Aprovada em 20 de junho de 2014. Diário Oficial da União, Brasília; 2014 [cited 2015 AUG 18]. Available from: http://www.agricultura.gov.br/comunicacao/noticias/2014/06/regraspara-sistemas-organicos-de-producao-sao-ajustadas.

Bonaudo T, Coutinho C, Poccard-Chapuis R, Lescoat P, Lossouarn J, Tourrand JF. Poutry industry and the sustainable development of territories: what links? What conditions? [cited 2013 Jul]. 2010. Available from: http:// hal.archives-ouvertes.fr/docs/00/52/28/00/PDF/Bonaudo_Poultryindustry.pdf.

Buainain AM, Batalha MO, Alcântara RLC. Cadeia produtiva de produtos orgânicos. Brasília: MAPA/SPA; 2007. 
Demattê Filho, LC. Sistema agroalimentar da avicultura fundada em princípios das Agricultura Natural: multifuncionalidade, desenvolvimento territorial e sustentabilidade [tese]. Piracicaba (SP): Escola Superior de Agricultura Luiz de Queiroz; 2014.

Demattê Filho LC, Marques PEM. Dinâmica tecnológica da cadeia industrial da avicultura alternativa. multifuncionalidade, desenvolvimento territorial e sustentabilidade. Segurança Alimentar e Nutricional $2011 ; 18(2): 1-11$

Ferreira DF. SISVAR: um programa para análises e ensino de estatística. Revista Symposium 2008;6(1):36-41.

Lisboa MM, Faria Filho RV, Pereira MMS, Silva JWD. Uso da colina na avicultura. Revista Eletrônica Nutritime 2014;11(6):375-379

Korin. Relatório geral para o conselho de administração Korin Empreendimentos e Participações Ltda. São Paulo: Korin Agricultura Natural; 2012.
Partridge IG, Low AG, Keal HD. A note on the effect of feeding frequency on nitrogen use in growing boars given diets with varying levels of free lysine. Animal Production 1985;40(2):375-377.

Rostagno HS, Albino LFT, Donzele JL, Gomes PC, Oliveira RF, Lopes DC, et al. Tabelas Brasileiras para vês e suínos: composição de alimentos e exigências nutricionais. 3rd ed. Viçosa: UFV Imprensa Universitária; 2011.

Sakamura NK, Rostagno HS. Métodos de pesquisa em nutrição de monogástricos. Jaboticabal: FUNEP; 2007

Silva MFR, Faria DE, Rizzoli PW, Santos AL, Sakamoto MI, Souza HRB Desempenho e qualidade dos ovos de poedeiras comerciais alimentadas com rações contendo diferentes níveis de metionina e lisina. Revista Brasileira de Zootecnia 2010;39(10):2246-2252.

UBABEF - União Brasileira de Avicultura; 2012 [cited 2013 Feb]. Available from: http://www.abef.com.br/ubabef/index.php. 
